\title{
A CASE FOR USING LITTER BREAKDOWN TO ASSESS FUNCTIONAL STREAM INTEGRITY
}

\author{
Mark O. Gessner ${ }^{1}$ And Eric Chauvet ${ }^{2}$ \\ ${ }^{1}$ Limnological Research Center, EAWAG/ETH, CH-6047 Kastanienbaum, Switzerland \\ ${ }^{2}$ Centre d'Ecologie des Systemes Aquatiques Continenteaux, CNRS-UPS, 29 Rue Jeanne Marvig, \\ 31055 Toulouse Cedex, France
}

\begin{abstract}
Assessment of the condition of ecosystems is a critical prerequisite for alleviating effects of the multiple anthropogenic stresses imposed on them. For stream ecosystems, a multitude of approaches has been proposed for this purpose. However, they all rest on the assessment of structural attributes, even though it is generally recognized that adequate characterization of ecosystems requires information on both structure (pattern) and function (process). Therefore, we propose a complementary approach to stream assessment based on evaluating ecosystem-level processes. Leaf litter breakdown is a prime candidate to consider in this context. This is because of the pivotal role that allochthonous litter plays in streams, the demonstrated effects of anthropogenic perturbations on litter breakdown, and the relative ease of implementation. Leaf breakdown is governed by a variety of internal and external factors that complicate the partitioning of effects due to anthropogenic stress and natural variability (background noise), thus potentially limiting the sensitivity and robustness of litter breakdown assays. However, internal regulation factors can be controlled by standardizing assessment procedures, while variability due to external factors can be accounted for by stream classificatio and/or a comparative approach (e.g., downstream-upstream comparisons). Composite parameters such as ratios of breakdown rates in fine-mes and coarse-mesh bags may further increase the power of litter breakdown assays. Analyses may also be extended to include both leaf-associated decomposer assemblages (i.e., structural measures) and processes (i.e., additional functional measures). Significan efforts are required for developing standard assessment schemes as refine as extant procedures based on structural stream attributes (e.g., structure of macroinvertebrate assemblages). These efforts are nevertheless worthwhile in view of the new dimension that is added to current assessment procedures when functional elements are incorporated.
\end{abstract}

Key words bioassessment; decomposition; ecological integrity; ecosystem health; ecosystemlevel process; environmental monitoring; functional integrity; leaf litter; river; stream.

\section{INTRODUCTION}

Streams, like other ecosystems, suffer from stresses imposed on them by human activities (e.g., Benke 1990, Zwick 1992, Allan and Flecker 1993, Dynesius and Nilsson 1994, Boon 2000). Stresses arise from environmental changes that occur at multiple scales. Relevant temporal scales range from hours to days (in the case of sudden events such as toxic spills) to decades and centuries in the case of long-term changes in landuse patterns (Harding et al. 1998) and climate (Rosenberg et al. 2000). Spatial scales include the stream channel proper, zones immediately adjacent to it, whole drainage basins, as well as much larger areas such as continents and the entire globe, through processes such as atmospheric nitrogen deposition or global warming. Societal awareness of these changes is growing, and both scientists and decision makers are seeking measures to alleviate the resulting negative effects (e.g., Convention on Biological Diversity 1992, Christensen

Manuscript received 24 July 2000; revised 10 May 2001; accepted 30 May 2001. et al. 1996, Stanford and Poole 1996, Ward 1998, Blöch 1999, Petts 1999). A critical prerequisite for such measures to be effective is assessment of the ecological state, or condition, of a stressed ecosystem. A multitude of approaches has been proposed for this purpose and a number of these are currently used by national and regional water authorities (e.g., Metcalfe-Smith 1994, Barbour et al. 1999, Norris and Thoms 1999, Jungwirth et al. 2000).

The concepts of ecological integrity and health provide a convenient framework for dealing with ecosystems affected by anthropogenic stresses. According to Karr (1991), ecological integrity (also known as biological, biotic, or ecosystem integrity) refers to a given state of a stream along a gradient of impairment that ranges from strongly impacted to pristine. More recently, the term ecological integrity has been reserved for the pristine endpoint of the impairment gradient only, whereas all other states represent different states of ecosystem health (Karr 1999). Ecosystem health thus embodies the notion of human values in the evaluation of ecosystems (Meyer 1997, Rapport et al. 1998), 
whereas the concept of ecological integrity resides on a purely scientifi base. The distinction between ecosystem integrity, in both its narrow and broad sense, and health is important. However, choice of one or the other concept and definitio will not affect the basic arguments laid out in the present article. For the purpose of this paper, we will therefore use the word integrity in a loose sense to cover all the possibilities above, and will only differentiate them specificall when necessary.

Ecological integrity can be subdivided into two components, structural and functional integrity (Minshall 1996). From a biological point of view, structure refers to spatiotemporal patterns, particularly of biological communities and their resources, and function can be equated with ecosystem-level processes. Structural integrity may thus be define as the qualitative and quantitative composition of biological communities and their resources under pristine conditions (to date largely hypothetical in most parts of the world; e.g., Hannah et al. 1994, Vitousek et al. 1997), or in an otherwise define reference situation, depending on which concept of ecosystem integrity or health is used. Fish and macroinvertebrate assemblages have been the main focus for assessing structural integrity (Metcalfe-Smith 1994, Barbour et al. 1999, Norris and Hawkins 2000, Statzner et al. 2001), although a variety of alternative targets such as benthic algal communities, protozoans, and macrophytes have also been used (e.g., Barbour et al. 1999, Norris and Thoms 1999, Hill et al. 2000).

Functional integrity is a complement to structural integrity and refers to the rates, patterns, and relative importance of different ecosystem-level processes under reference conditions. Functional integrity define in this way (i.e., in terms of ecosystem processes) is not currently considered in systematic assessments of the ecological conditions of streams (Bunn and Davies 2000). Thus the main purposes of the present paper are to provide a rationale for using ecosystem-level processes in stream assessment, to examine potentials and potential limitations for using leaf litter breakdown as an indicator process, and to provide a framework for working out the details of assessment procedures.

\section{Ecosystem-Level Processes as a Measure of STREAM INTEGRITY}

At present, officia schemes for stream assessment rest almost exclusively on structural attributes of streams. This restriction is in contrast with the way ecologists view ecosystems, viz., as entities define by both structure and function (e.g., Cummins 1974, Chapin et al. 1997). Because pattern (structure) determines process (function) and processes in turn affect patterns, both are linked. Structure and function nevertheless describe different aspects of the same entity, comparable to the two sides of a coin. Consequently, both must be considered if the integrity of an ecosystem as a whole is to be assessed (Matthews et al. 1982,
Bunn and Davies 2000). Restriction to structural attributes ignores the complementary nature of pattern and process, thereby precluding comprehensive ecosystem assessment. This is the cardinal reason why, in our opinion, functional measures need to be incorporated into bioassessment schemes.

That changes in pattern do not always equate to changes in functional ecosystem attributes is not just a theoretical argument but has been demonstrated in experimental studies. Matthews et al. (1982) distinguish three possible outcomes in the response of structural and functional ecosystem attributes to stress: (1) structural changes without modificatio of functional parameters, (2) functional changes without alteration of community structure, and (3) changes in both structure and function. An example of the firs case is provided by Nelson's (2000) study showing that macroinvertebrate community structure responded more sensitively to metal pollution than leaf breakdown in a high-altitude stream. The second case is illustrated by a study on gross primary production and community respiration (Bunn and Davies 2000). These processes clearly responded to nitrogen enrichment and increased stream water turbidity, whereas macroinvertebrate community structure, determined with an officia assessment protocol, AusRivAS, failed to detect these stresses (Bunn and Davies 2000). Another example is provided by a study on periphyton in outdoor stream channels, where Rodgers et al. (1979) found primary production to be a better measure than biofil structure for identifying experimentally induced stresses. The third case is illustrated by the study of Leland and Carter (1985). They observed that rates of algal biomass accumulation, and microbial respiration on and immobilization by decomposing litter were markedly depressed following copper additions, in line with copper-induced changes in periphyton community composition. Similarly, effects on several ecosystem processes (litter breakdown, generation and export of fine particulate organic matter, secondary production of macroinvertebrates) corresponded to changes in standard biotic indices following experimental insecticide treatment of a stream (Wallace et al. 1996).

A number of additional arguments can be advanced in favor of using ecosystem processes in bioassessment (Bunn and Davies 2000). Like other biological variables, biologically driven processes provide an integrative measure of ecosystem integrity (Webster and Benfiel 1986). Integration may work not only over time (Bunn et al. 1999), but also across organisms at different organizational levels. For example, litter decomposition in streams involves organisms ranging from bacteria and fungi to invertebrates and, in the tropics, fishes suggesting that anthropogenic stresses on leaf breakdown can become effective through various targets and mechanisms.

A further argument is that process analyses depict a more general picture than the structure of stream biota 
because processes are not critically dependent on the presence of a specifi set of species. Processes are thus much less dependent on the geographical setting (e.g., Hunsaker et al. 1990, Bunn and Davies 2000). Compared to structural measures, this constitutes an advantage in practice, particularly when assessment schemes are to be standardized among geographically distinct regions possessing diverging species complements (e.g., in different regions within the United States or Australia, or countries within the European Union). Furthermore, taxonomic expertise is not normally required.

Even a cursory comparison of current approaches to bioassessment of streams and lakes illustrates how strongly tradition appears to influenc ways of assessing ecosystem integrity. Bioassessment of lakes has traditionally been based on a functional ecosystem attribute (i.e., evaluation of the intensity of primary production, the most fundamental of all ecosystem processes). This approach has been extremely successful both scientificall and in terms of environmental improvement. The scientifi success was due to the fact that cause (enhanced nutrient loading) and effect (e.g., increased algal production, hypolimnetic oxygen depletion, fis kill) were mechanistically linked, while success in terms of environmental policy was facilitated by effective translation of scientifi understanding into political action, ultimately resulting in large-scale re-oligotrophication of lakes (e.g., Smith 1998). An instructive side issue of this re-oligotrophication success story is that planktologists commonly complain about the lack of structural criteria in the assessment of lake status, especially about the neglect of phytoplankton species composition. Clearly, stream bioassessment has gone the opposite way by focusing on structural ecosystem attributes and neglecting functional aspects.

Functional aspects of stream integrity have nevertheless been addressed indirectly (Merritt et al. 1999, Rawer-Jost et al. 2000, Statzner et al. 2001). These approaches are based on analyses of macroinvertebrate assemblages in terms of proportions of functionally define groups, such as Cummins's (1974) functional feeding groups, and have even been included in the Rapid Bioassessment Protocols of the U.S. Environmental Protection Agency (Barbour et al. 1999). Although this functional group approach can be a useful complement to the examination of ecosystem processes, it must be borne in mind that it deduces information about ecosystem-level processes indirectly from the analysis of structural parameters. If or to what extent the information thus gained can serve as proxy for direct evaluation of ecosystem-level processes remains to be demonstrated.

\section{EXAMPLES OF ECOSYSTEM-LEVEL Processes IN STREAMS}

There are a variety of ecosystem-level processes that might be used in stream bioassessment (Reice and
Wohlenberg 1993, Minshall 1996). Possible target processes include primary production of benthic algae (Rodgers et al. 1979, Leland and Carter 1985, Hill et al. 1997, Sabater et al. 1998, Bunn et al. 1999, Young and Huryn 1999) and macrophytes (Niemi et al. 1993), community respiration (Niemi et al. 1993, Hill et al. 1997, Bunn et al. 1999, Young and Huryn 1999), sediment respiration (Hill et al. 1998), secondary production of macroinvertebrates (Wallace et al. 1996), nitrogen fixatio (Leland and Carter 1985), enzymatic transformations in epilithic biofilm (Sabater et al. 1998, Hill et al. 2000), and litter decomposition (Table 1). These processes may be driven either by diverse consortia of organisms or by rather specifi groups such as the nitrifying or methanogenic bacteria. Other processes contain both biotic and abiotic components. The export of fine-particulat organic matter (Wallace et al. 1996) and the retention of dissolved nutrients are examples. In addition, purely abiotic processes, such as hydrological and geomorphological ones, or other large-scale processes involving biological elements (e.g., island dynamics) could be used in stream assessment. To date, only a rather small number of processes have even been considered for assessing stream integrity. This is in striking contrast to the immense investments made in working out metrics for examining macroinvertebrate assemblages (e.g., Rosenberg and Resh 1993, Metcalfe-Smith 1994, Barbour et al. 1999, Statzner et al. 2001). Thus it is clear that considerably more thought and empirical study must be devoted to determining which ecosystem-level processes can serve as good indicators of functional integrity.

One of the challenges is to identify the processes most useful in specifi kinds of stress situations. Although comprehensive data sets are needed to make sound recommendations, ecological theory and a few data available at present already allow the pinpointing of potentially useful processes. For example, primary production of benthic algae would be expected to be an excellent indicator process in cases where light regimes of streams are altered. This could be the result of changes in riparian canopy cover (Sabater et al. 1998) or increased turbidity (Bunn and Davies 2000) accompanying intensifie land use. As much as $68 \%$ of the variability in instream primary production was explained by the percent canopy cover of 15 streams whose riparian and catchment vegetation was disturbed to various degrees (Bunn and Davies 2000). The percent catchment cover by crops and pasture explained an additional $14 \%$ of the differences in instream primary production. Likewise, nutrient enrichment from both point and non-point sources (i.e., atmospheric depositions, agricultural runoff, sewage effluent) which may be exacerbated by reduced flo as a result of water abstraction, are likely to be reflecte in levels of primary productivity. Stream acidification in contrast, will not entail measurable effects if the production of epiphytic algal communities shows similar compen- 
TABLE 1. Range of ratios of leaf litter breakdown coefficient at impacted $\left(k_{\mathrm{i}}\right)$ and reference $\left(k_{\mathrm{r}}\right)$ stream sites for different types of anthropogenic stresses.

\begin{tabular}{|c|c|c|c|c|c|c|}
\hline $\begin{array}{l}\text { Type of } \\
\text { stress }\end{array}$ & $k_{\mathrm{i}}: k_{\mathrm{r}}(\%)$ & Plant species & $\begin{array}{l}\text { Stream } \\
\text { order } \dagger\end{array}$ & Study sites & Location & Reference \\
\hline \multicolumn{7}{|c|}{ A) Stream water quality } \\
\hline Copper & $45-55$ & Acer rubrum & $1 / 2$ & $\begin{array}{l}3 \text { impacted down- } \\
\text { stream sites vs. } \\
1 \text { upstream ref- } \\
\text { erence site }\end{array}$ & VA, USA & $\begin{array}{l}\text { Schultheis et } \\
\text { al. (1997) }\end{array}$ \\
\hline Zinc & $18-125$ & Salix spp. & & $\begin{array}{l}18 \text { impacted vs. } 9 \\
\text { reference sites }\end{array}$ & $\mathrm{CO}, \mathrm{USA}$ & $\begin{array}{l}\text { Niyogi et al. } \\
(2001)\end{array}$ \\
\hline Metals & $22-34$ & Alnus tenuifolia & 3 & $\begin{array}{l}1 \text { untreated and } 1 \\
\text { treated down- } \\
\text { stream site vs. } \\
\text { corresponding } \\
\text { reference sites } \\
\text { upstream }\end{array}$ & $\mathrm{CO}, \mathrm{USA}$ & $\begin{array}{l}\text { Gray and } \\
\text { Ward } \\
\text { (1983) }\end{array}$ \\
\hline \multirow[t]{3}{*}{ Coal } & $85 \ddagger$ & Alnus glutinosa & river & $\begin{array}{l}1 \text { impacted down- } \\
\text { stream vs. } 1 \text { up- } \\
\text { stream reference } \\
\text { site }\end{array}$ & UK & $\begin{array}{l}\text { Maltby and } \\
\text { Booth } \\
\text { (1991) }\end{array}$ \\
\hline & $31-55$ & $\begin{array}{l}\text { Alnus glutinosa, } \\
\text { Acer pseudo- } \\
\text { platanus }\end{array}$ & river & $\begin{array}{l}1 \text { impacted down- } \\
\text { stream vs. } 1 \text { up- } \\
\text { stream reference } \\
\text { site }\end{array}$ & UK & $\begin{array}{l}\text { Bermingham } \\
\text { et al. } \\
\text { (1996) }\end{array}$ \\
\hline & $54-72$ & Alnus serrulata & 1 & $\begin{array}{l}2 \text { impacted streams } \\
\text { vs. } 1 \text { adjacent } \\
\text { reference stream }\end{array}$ & AL, USA & $\begin{array}{l}\text { Scheiring } \\
\quad(1993)\end{array}$ \\
\hline \multirow[t]{2}{*}{$\begin{array}{l}\text { 2) Acidic } \\
\text { precipitation }\end{array}$} & 11 & Fagus sylvatica & 2 & $\begin{array}{l}1 \text { acidifie vs. } 1 \\
\text { adjacent refer- } \\
\text { ence stream }\end{array}$ & France & $\begin{array}{l}\text { Dangles and } \\
\text { Guérold } \\
\text { (1998) }\end{array}$ \\
\hline & 68 & $\begin{array}{l}\text { Fraxinus ameri- } \\
\quad \text { cana }\end{array}$ & 1 & $\begin{array}{l}1 \text { acidifie vs. } 1 \\
\text { reference stream }\end{array}$ & PA, USA & $\begin{array}{l}\text { Kimmel et } \\
\text { al. (1985) }\end{array}$ \\
\hline \multirow{2}{*}{$\begin{array}{l}\text { 3) Other chemicals } \\
\text { Chlorine }\end{array}$} & & & & & & \\
\hline & $57-105$ & $\begin{array}{l}\text { Potamogeton } \\
\text { crispus }\end{array}$ & & $\begin{array}{l}1 \text { manipulated } \\
\text { downstream vs. } \\
1 \text { upstream ref- } \\
\text { erence site in } \\
\text { each of } 4 \text { experi- } \\
\text { mental streams }\end{array}$ & MN, USA & $\begin{array}{l}\text { Newman et } \\
\text { al. (1987) }\end{array}$ \\
\hline $\begin{array}{l}\text { Chlorine plus } \\
\text { ammonia }\end{array}$ & $27-136$ & $\begin{array}{l}\text { Potamogeton } \\
\text { crispus }\end{array}$ & & $\begin{array}{l}1 \text { downstream ma- } \\
\text { nipulated vs. } 1 \\
\text { upstream refer- } \\
\text { ence of } 7 \text { experi- } \\
\text { mental streams }\end{array}$ & MN, USA & $\begin{array}{l}\text { Newman and } \\
\text { Perry } \\
\text { (1989) }\end{array}$ \\
\hline$p$-Cresol & $75-134$ & Populus deltoides & & $\begin{array}{l}2 \text { manipulated vs. } \\
2 \text { reference ex- } \\
\text { perimental } \\
\text { stream channels }\end{array}$ & WI, USA & $\begin{array}{l}\text { Stout and } \\
\text { Cooper } \\
(1983)\end{array}$ \\
\hline Insecticide & $42-49$ & $\begin{array}{l}\text { Acer rubrum, } \\
\text { Rhododendron } \\
\text { maximum }\end{array}$ & 1 & $\begin{array}{l}2 \text { manipulated } \\
\text { streams vs. the } \\
\text { same } 2 \text { streams } \\
\text { prior to manipu- } \\
\text { lation and } 1 \text { in- } \\
\text { dependent refer- } \\
\text { ence stream }\end{array}$ & $\mathrm{NC}$, USA & $\begin{array}{l}\text { Whiles et al. } \\
\text { (1993) }\end{array}$ \\
\hline $\begin{array}{l}\text { 4) Nutrients } \\
\text { Nitrate }\end{array}$ & $85-190$ & $\begin{array}{l}\text { Acer circinatum, } A . \\
\text { macrophyllum, } \\
\text { Alnus rubra, } \\
\text { Pseudotsuga } \\
\text { menziesii }\end{array}$ & & $\begin{array}{l}2 \text { manipulated vs. } \\
1 \text { reference ex- } \\
\text { perimental } \\
\text { stream channel }\end{array}$ & WA, USA & $\begin{array}{l}\text { Triska and } \\
\text { Sedell } \\
(1976)\end{array}$ \\
\hline & $278-289$ & $\begin{array}{l}\text { Betula lenta, } \\
\text { Robinia pseudo- } \\
\text { acacia }\end{array}$ & 1 & $\begin{array}{l}1 \text { impacted vs. } 1 \\
\text { adjacent refer- } \\
\text { ence stream }\end{array}$ & NC, USA & $\begin{array}{l}\text { Meyer and } \\
\text { Johnson } \\
(1983)\end{array}$ \\
\hline & $164-760$ & $\begin{array}{l}\text { Liriodendron } \\
\text { tulipifera }\end{array}$ & $1 / 2$ & $\begin{array}{c}7 \text { high-nutrient vs. } \\
3 \text { adjacent low- } \\
\text { nutrient streams }\end{array}$ & AL, USA & $\begin{array}{l}\text { Suberkropp } \\
\text { and Chau- } \\
\text { vet (1995) }\end{array}$ \\
\hline
\end{tabular}


TABLE 1. Continued.

\begin{tabular}{|c|c|c|c|c|c|c|}
\hline $\begin{array}{l}\text { Type of } \\
\text { stress }\end{array}$ & $k_{\mathrm{i}}: k_{\mathrm{r}}(\%)$ & Plant species & $\begin{array}{l}\text { Stream } \\
\text { order } \uparrow\end{array}$ & Study sites & Location & Reference \\
\hline \multirow[t]{2}{*}{ Phosphate } & $120-127$ & Quercus rubra & 2 & $\begin{array}{l}1 \text { manipulated vs. } \\
1 \text { reference site in } \\
\text { each of } 2 \text { streams }\end{array}$ & TN, USA & $\begin{array}{l}\text { Elwood et } \\
\text { al. (1981) }\end{array}$ \\
\hline & 207 & Alnus viridis & 1 & $\begin{array}{l}\text { Fertilized vs. un- } \\
\text { fertilized leaf } \\
\text { packs in a single } \\
\text { stream }\end{array}$ & Switzerland & $\begin{array}{l}\text { Robinson } \\
\text { and Gessner } \\
(2000)\end{array}$ \\
\hline \multicolumn{7}{|c|}{$\begin{array}{l}\text { B) Vegetation } \\
\text { 1) Plantation of exotic } \\
\text { tree species }\end{array}$} \\
\hline Pine & $31 \S$ & $\begin{array}{l}\text { Pinus strobus, Acer } \\
\quad \text { rubrum }\end{array}$ & 1 & $\begin{array}{l}2 \text { impacted vs. } 2 \\
\text { reference hard- } \\
\text { wood forest } \\
\text { streams }\end{array}$ & NC, USA & $\begin{array}{l}\text { Whiles and } \\
\text { Wallace } \\
\text { (1997) }\end{array}$ \\
\hline \multirow[t]{2}{*}{ Eucalypt } & $23-59 \S$ & $\begin{array}{l}\text { Eucalyptus globu- } \\
\text { lus, Alnus gluti- } \\
\text { nosa }\end{array}$ & 1 & $\begin{array}{l}2 \text { impacted streams } \\
\text { vs. } 1 \text { adjacent } \\
\text { reference stream }\end{array}$ & Spain & $\begin{array}{l}\text { Pozo et al. } \\
\quad(1998)\end{array}$ \\
\hline & $72 \ddagger, \S$ & $\begin{array}{l}\text { Eucalyptus globu- } \\
\text { lus, Castanea } \\
\text { sativa }\end{array}$ & $1-5$ & $\begin{array}{l}3 \text { impacted vs. } 3 \\
\text { adjacent refer- } \\
\text { ence streams }\end{array}$ & Portugal & $\begin{array}{l}\text { Abelho and } \\
\text { Graça } \\
\text { (1996) }\end{array}$ \\
\hline \multirow[t]{2}{*}{ Willow } & 800 & $\begin{array}{l}\text { Salix babylonica, } \\
\text { Eucalyptus } \\
\text { blakelyi }\end{array}$ & 3 & 1 impacted stream & Australia & $\begin{array}{l}\text { Pidgeon and } \\
\text { Cairns } \\
\text { (1981) }\end{array}$ \\
\hline & $186-214 \S$ & $\begin{array}{l}\text { Salix babylonica, } \\
\text { Eucalyptus ca- } \\
\text { maldulensis }\end{array}$ & river & $\begin{array}{l}3 \text { impacted vs. } 3 \\
\text { adjacent refer- } \\
\text { ence sites }\end{array}$ & Australia & $\begin{array}{l}\text { Schulze and } \\
\text { Walker } \\
\text { (1997) }\end{array}$ \\
\hline \multirow[t]{3}{*}{ 2) Logging } & $116-494$ & $\begin{array}{l}\text { Cornus florida } \\
\text { Acer rubrum, } \\
\text { Liriodendron tu- } \\
\text { lipifera, Rhodo- } \\
\text { dendron maxi- } \\
\text { mum }\end{array}$ & 2 & $\begin{array}{l}3 \text { impacted streams } \\
\text { vs. } 1 \text { adjacent } \\
\text { reference stream }\end{array}$ & NC, USA & $\begin{array}{l}\text { Benfiel et } \\
\text { al. (1991) }\end{array}$ \\
\hline & 142 & Acer saccharum & 2 & $\begin{array}{l}1 \text { impacted vs. } 1 \\
\text { reference stream }\end{array}$ & VA, USA & $\begin{array}{l}\text { Griffit and } \\
\text { Perry } \\
(1991)\end{array}$ \\
\hline & $100-284$ & $\begin{array}{l}\text { Cornus florida } \\
\text { Acer rubrum, } \\
\text { Rhododendron } \\
\text { maximum }\end{array}$ & 2 & $\begin{array}{l}1 \text { stream, before } \\
\text { and after pertur- } \\
\text { bation }\end{array}$ & NC, USA & $\begin{array}{l}\text { Webster and } \\
\text { Waide } \\
\text { (1982) }\end{array}$ \\
\hline \multirow[t]{3}{*}{ 3) Agriculture } & $292 \$, \|$ & $\begin{array}{l}\text { Chionochloa rigida } \\
\text { or C. rubra }\end{array}$ & & $\begin{array}{l}3 \text { impacted vs. } 3 \\
\text { reference } \\
\text { streams }\end{array}$ & New Zealand & $\begin{array}{l}\text { Young et al. } \\
\text { (1994) }\end{array}$ \\
\hline & $69-138 \|$ & Acer saccharum & & $\begin{array}{l}1 \text { impacted vs. } 1 \\
\text { forested refer- } \\
\text { ence stream }\end{array}$ & $\begin{array}{l}\text { Ontario, } \\
\text { Canada }\end{array}$ & $\begin{array}{l}\text { Bird and } \\
\text { Kaushik } \\
\text { (1992) }\end{array}$ \\
\hline & 131 & Quercus alba & 2 & $\begin{array}{l}2 \text { impacted sites } \\
\text { vs. } 1 \text { forested } \\
\text { reference site } \\
\text { upstream }\end{array}$ & MI, USA & $\begin{array}{l}\text { Tuchman } \\
\text { and King } \\
\text { (1993) }\end{array}$ \\
\hline \multicolumn{7}{|l|}{ C) Miscellaneous } \\
\hline $\begin{array}{l}\text { 1) Highway } \\
\text { construction }\end{array}$ & $25-2639$ & Quercus alba & $3 / 5$ & $\begin{array}{l}4 \text { impacted vs. } 2 \\
\text { reference sites }\end{array}$ & TN, USA & $\begin{array}{l}\text { Stout and } \\
\text { Coburn } \\
(1989)\end{array}$ \\
\hline $\begin{array}{l}\text { 2) Stream } \\
\text { regulation }\end{array}$ & 197 & Alnus tenuifolia & river & $\begin{array}{l}1 \text { impacted vs. } 1 \\
\text { adjacent refer- } \\
\text { ence stream }\end{array}$ & $\mathrm{CO}, \mathrm{USA}$ & $\begin{array}{l}\text { Short and } \\
\text { Ward } \\
(1980)\end{array}$ \\
\hline $\begin{array}{l}\text { 3) Thermal } \\
\text { pollution }\end{array}$ & $139-307$ & $\begin{array}{l}\text { Acer saccharum, A. } \\
\text { negundo, Cornus } \\
\text { florida Platanus } \\
\text { occidentalis }\end{array}$ & river & $\begin{array}{l}1 \text { impacted vs. } 1 \\
\text { upstream refer- } \\
\text { ence site }\end{array}$ & VA, USA & $\begin{array}{l}\text { Paul et al. } \\
\text { (1978) }\end{array}$ \\
\hline
\end{tabular}

Notes Some of the breakdown coefficient used for calculating ratios were calculated from graphs or tabulated data in the respective papers. State abbreviations: VA, Virginia; CO, Colorado; AL, Alabama; PA, Pennsylvania; MN, Minnesota; WI, Wisconsin; NC, North Carolina; WA, Washington; TN, Tennessee; MI, Michigan.

$\dagger$ An empty cell indicates that the stream order cannot be inferred from the cited reference.

Calculated from reported linear breakdown coefficients

$\S$ Breakdown of exotic species in impacted streams vs. that of native species in reference streams.

|| Data from several seasons.

T Values depend on the type of investigated site and mesh size. 
satory responses to lowered $\mathrm{pH}$ as lake phytoplankton (e.g., Schindler 1987). This prediction contrasts with the consistently observed and occasionally dramatic effect of lowered $\mathrm{pH}$ on leaf litter breakdown, a process that has been shown also to be affected by changes in riparian vegetation and nutrient enrichment (Table 1; Webster and Benfiel 1986). Similarly, organic matter transformations by heterotrophic biofilm may be good indicators of land use alterations, such as large-scale drainage and wetland elimination, which can affect the dynamics of dissolved organic matter (Gergel et al. 1999) on which heterotrophic biofil metabolism depends. Such organic matter transformations can be measured by means of simple enzymatic assays (e.g., Sinsabaugh et al. 1991). The retention of carbon and nutrients also will be influence by the extent of biofil development (Martí et al. 1997), and is likely to indicate a lack of bed-forming spates as occurs often below impoundments and water diversion devices. Finally, anaerobic processes, such as denitrificatio and methanogenesis, may be particularly sensitive indicators of a lack of spates and/or increased sediment load when resulting in clogging of the stream bottom.

The remainder of this paper will focus mainly on litter breakdown. This process is currently best documented by both a comprehensive set of background data and specifi information on effects of anthropogenic disturbances (Anderson and Sedell 1979, Webster and Benfiel 1986, Maltby 1992, Webster et al. 1995, Gessner et al. 1997, 1999, Suberkropp 1998). In addition, leaf litter and its breakdown play pivotal roles in stream food webs and energetics (Cummins et al. 1989, Gregory et al. 1991, Graç a 1993, Webster et al. 1995, 1999, Wallace and Webster 1996, Wallace et al. 1997, Webster and Meyer 1997, Suberkropp 1998). The breakdown process thus suggests itself as a starting point for developing a diagnostic tool to assess functional stream integrity. However, many of the principles and arguments developed below apply to other ecosystem processes as well. Primary production in streams has also been studied to a considerable extent, sometimes in relation to anthropogenic disturbances, and is clearly another prime candidate for assessing functional integrity. Likewise, other processes may turn out to be powerful functional indicators once sufficien empirical data have been collected.

\section{Demonstrated EfFects of Anthropogenic STRESS ON LitTER BREAKDOWN}

A prerequisite for using any type of indicator of ecosystem integrity is that it responds unequivocally to anthropogenic stresses. Such effects have been demonstrated in a number of case studies on litter breakdown in streams (Table 1; Webster and Benfiel 1986). Pollution by mine drainage is among the best documented stressors affecting the process, with most pertinent investigations documenting a strong reduction in breakdown rates (Table 1), regardless of whether streams receive pretreated or untreated mine effluent (Gray and Ward 1983). For example, leaf breakdown rates were reduced by half at three sites impacted by pyrite mine drainage effluents where stream water exhibited copper concentrations two orders of magnitude higher than at an upstream reference site (Schultheis et al. 1997). Taxonomic richness and abundance of benthic macroinvertebrates was also reduced at the impacted sites, but recovered after a treatment system was put in operation. This alleviation did not, however, translate into a similar recovery of leaf breakdown, suggesting that functional stream integrity remained impaired. In the most comprehensive study to date, Niyogi et al. (2001) likewise found a significan negative correlation between leaf breakdown rate and concentrations of dissolved zinc at 27 stream sites differing in extent and type of pollution originating from mining activities. Slower leaf breakdown also occurred downstream of a coal mine effluen carrying high metal loads (Maltby and Booth 1991, Bermingham et al. 1996) as well as in other similarly impacted systems (Table 1).

Stream acidificatio through atmospheric inputs and related impacts (e.g., elevated aluminum concentrations) can have similarly striking effects on litter breakdown (Table 1), especially in poorly buffered softwater streams. A particularly strong effect has been reported from a stream in the Vosges Mountains of France that drains a catchment underlain by granite and sandstone bedrock (Dangles and Guérold 1998). Even under circumneutral conditions, leaves of the dominant deciduous tree species in the area (Fagus sylvatica) decompose slowly (breakdown coefficien $k$ of $0.0018 / d$ ). At $\mathrm{pH} 4.5$, breakdown was virtually halted; a mass loss of only $\sim 3 \%$ was observed eight months after exposure of leaves in the stream $(k=0.0002 / \mathrm{d})$. As a result, breakdown rates were as much as nine times lower than in an adjacent circumneutral stream (average $\mathrm{pH}$ of 7.2; Dangles and Guérold 1998) and even >20 times lower $(k=0.0045 / \mathrm{d})$ than in another softwater mountain stream in the same country (Gessner and Chauvet 1994). These results were later confi med in a study involving seven headwater streams (Dangles and Guérold 2001), and are also consistent with a range of other studies demonstrating that decreases in stream $\mathrm{pH}$ are accompanied by reduced litter breakdown rates (Table 1; Webster and Benfiel 1986). The broad agreement across studies addressing both point and nonpoint pollution in different regions indicates that leaf breakdown rate is an excellent indicator of functional ecosystem impairment resulting from stream water acidificatio and related stresses.

A variety of other published reports illustrate the utility of litter breakdown to assess the effect of anthropogenic stresses on stream integrity (Table 1; Webster and Benfiel 1986). Modificatio of riparian vegetation is among the most obvious impacts (Vought et al. 1998, Stevens and Cummins 1999), as the composition and density of streamside vegetation affects 
litter inputs to streams and, consequently, the litter breakdown process. Logging activities in the watershed, including road construction, have been shown to result in pronounced effects (Benfiel et al. 2001, Abelho and Graç a 1996, Pozo et al. 1998), as can unwilling replacement of natural riparian vegetation (Smock and McGregor 1988). Changes in plant species composition may result in either slower or faster breakdown of the leaf litter entering the affected streams (Table 1; Webster and Benfiel 1986).

A striking example of altered breakdown rates comes from a whole-stream study involving long-term experimental application of an insecticide (Chung et al. 1993, Whiles et al. 1993, Wallace et al. 1996). Breakdown of two leaf species was greatly depressed as long as the insecticide treatment continued, whereas in nearby reference streams, interannual variation in litter breakdown rates was small. This observation, together with the similar breakdown rates in control and treated streams in the years prior to insecticide application, suggests that rates of leaf breakdown were reduced primarily because of the experimental elimination of insect fauna. This effect was not compensated for (or not fully so) by microbial activity, although leaf-degrading fungi did not appear to be affected by the insecticide (Suberkropp and Wallace 1992). In contrast, a dramatic decline of detritivorous invertebrates (shredders) at sites affected by treated sewage effluent corresponded to an increase in breakdown rates in the study by Pascoal et al. (2001). This suggests that a stimulation of microbial activity (e.g., by enhanced nutrient availability; Grattan and Suberkropp 2001) even overcompensated the decline of shredders. If breakdown rates had not been determined and functioning of the system had been deduced from changes in macroinvertebrate community structure (i.e., the abundance and relative proportion of shredders), the conclusions of this study about system functioning would have been exactly opposite to the real effect.

In the second year after the insecticide treatment was discontinued in the study by Wallace et al. (1996), breakdown rates increased greatly, such that they significantl exceeded the rates observed both before the treatment and in the reference stream. This acceleration suggests that during recovery from poisoning, leaf breakdown became impaired in a different, but similarly severe, way than during the treatment. These find ings call attention to at least two points for consideration in developing bioassessment schemes based on ecosystem-level processes. First, process rates can deviate from normal by either a depression or acceleration, and second, stressors may induce secondary effects (cf. Frost et al. 1999) that can operate at different time scales than the straightforward primary effect.

\section{Potential Limitations in Perspective}

Using ecosystem-level processes for assessing the ecological integrity of streams potentially poses a num- ber of problems. At least three objections may be raised. One criticism is that functional measures are technically difficul and/or time consuming, and therefore not cost effective (e.g., Matthews et al. 1982, Crossey and La Point 1988). Compared to some simple structural measures, the assessment of processes may indeed be more complicated and expensive (Wallace et al. 1996); however, this is not invariably so (Bruns et al. 1992, Reice and Wohlenberg 1993, Young et al. 1994, Minshall 1996). For example, manipulation of some standard leaf packs and measurement of simple integrative parameters associated with them, such as the difference in mass over a define period, is clearly straightforward compared to the determination of structural measures involving species inventories. Species inventories not only tend to be laborious but also require specifi expertise. In a comparative cost analysis, it has indeed been shown that the determination of process rates need not be more expensive than quantifying even simple parameters of biological structure, such as total macroinvertebrate density or periphyton biomass (Niemi et al. 1993). Thus criticism relating to high cost and effort does not inevitably apply to the assessment of ecosystem-level processes, but must be carefully considered in the individual case. Moreover, should time constraints, technical difficulties and costs (within certain acceptable limits) be striking arguments if only a part of ecosystem integrity is assessed when the complementary functional component is ignored?

Another argument relates to the idea that ecosystemlevel processes do not respond sensitively enough to anthropogenic stress. To some extent this issue constitutes a fundamental dilemma. This is because indicators of ecosystem integrity (both functional and structural ones) need to meet two partially incongruent requirements; they must respond to even minor changes in the environmental factor(s) of interest yet vary little in response to other variables. The underlying rationale is that false signals are avoided (i.e., indication of effects that do not exist) while real effects are detected even when they are small (Bunn and Davies 2000). This double requirement can become inextricable when generality is sought in the sense that a given metric is to indicate impairments resulting from a multitude of stress types occurring at different scales. In practice, ideal indicators will thus be difficul to find making trade-offs among generality, sensitivity, and robustness inevitable.

The putative caveat of limited sensitivity has several other components that need to be considered separately. Low sensitivity can arise from natural variability, method-related variability, or compensatory effects within species assemblages that can occur when a stress factor affects some types of organisms involved in the process but not others. Only the last point is specifi to the use of ecosystem-level processes in bioassessment, the former two affect structural indicators alike. Currently, concerns about compensatory responses are based more 
on intuition than on facts from empirical work in streams. However the point is not easily refuted, and because sensitivity is critically important for any measure of ecosystem integrity, the pertinence of compensatory effects must be seriously examined. Empirical work on specifi processes in specifi situations is needed to provide conclusive answers.

Data from long-term experimental manipulations of lakes highlight the intricate nature of the compensatory response issue. Pelagial primary production responds sensitively to the addition of limiting nutrients, which in most lakes is phosphorus (Smith 1998), but reduction in phosphorus loading does not always result in immediate decreases in primary production. Acidificatio is another important stress imposed on lakes, which in contrast to the clear-cut results from nutrient loading, has not induced changes in primary production in experimental studies (e.g., Schindler 1987). Secondary production of zooplankton also remained unchanged following decreases in lake water $\mathrm{pH}$, even though the zooplankton community composition changed distinctly (Frost et al. 1995). Strong compensatory effects are thus indicated. Nitrification in contrast, completely ceased even after an initial moderate lowering of $\mathrm{pH}$ to a value of 5.8 (Rudd et al. 1988), and other microbial processes appeared to be affected as well (Frost et al. 1999). These contrasting outcomes from nutrient addition and acidificatio experiments, and the varied responses of different processes to acidification illustrate that a given process may respond sensitively to one type of anthropogenic stress while showing virtually no response to another type, even if it is severe. Therefore, a key challenge, in view of identifying indicators of functional integrity, is to ascertain which kinds of stresses lead to predictable changes of which ecosystem-level processes under which circumstances.

In addition to compensatory effects, sensitivity of ecosystem processes is reduced by both natural and method-related variability (e.g., Webster and Benfiel 1986, Young and Huryn 1999). Assays based on ecosystem processes must be able to cope with the resulting background noise, just like any other assessment tool. This challenge can be met by standardization. Possible sources of variability are differences in experimental procedures. For example, in litter breakdown assays, exposure technique (e.g., leaf bag vs. leaf pack), mesh size of leaf bags, and size and location of leaf packs in a stream (e.g., pool vs. riffle are variables that need to be controlled. There are also differences in breakdown rates among leaf species (Petersen and Cummins 1974, Webster and Benfiel 1986, Gessner and Chauvet 1994). Timing of assays in phase with natural leaf inputs is another aspect to be taken into account (Maloney and Lamberti 1995, Baldy and Gessner 1997). However, proper timing of assays is as straightforward as standardization of leaf species and experimental procedures. Consequently, none of the sources of background noise related to methodological aspects should compromise the sensitivity of litter breakdown assays in a serious way. Likewise, when accounting for methodological effects, Young and $\mathrm{Hu}-$ ryn (1999) observed that landscape features affected ecosystem processes markedly, in particular the ratio of two key processes, gross primary production and community respiration.

The reduction of background noise resulting from natural variability is a greater challenge than methodrelated variability. Differences in litter breakdown rates, for example, may be large across streams (Hill et al. 1992, Suberkropp and Chauvet 1995, Webster et al. 1995). Stream size, geographical location, and water chemistry (e.g., ionic content, nutrient availability) are some of the potentially confounding factors. Controlling these factors is essential in those cases where appropriate reference systems are unavailable for direct comparison (e.g., comparisons before-after, upstreamdownstream or, more generally speaking, between disturbed and corresponding reference sites). Stream classificatio thus becomes a key issue in developing assays relying on ecosystem processes, just as is the case for structural parameters (Karr 1999).

A Framework for Assessing Functional Stream InTEGRITy Using LitTer Breakdown AS AN INDICATOR PRocess

An important issue apart from standardization is the choice of the specifi parameters that characterize the litter breakdown process. Parameters reflectin the speed of breakdown are the most obvious to consider. For example, breakdown rate coefficient ( $k$ values) calculated by regressing leaf mass remaining of standard leaf packs against time may be used. Breakdown coefficient based on an exponential decay model are the standard measure reported in the literature on litter breakdown in streams (Petersen and Cummins 1974, Suberkropp 1998); such models may, or may not, compensate for temperature effects (Cummins et al. 1989). Alternatively, the time needed to achieve $50 \%$ or $95 \%$ mass loss from standard leaf packs may be chosen (Wallace et al. 1996). Another possibility is the percent of litter mass remaining after a define period that leaves were exposed in a stream (Maltby et al. 1995, Jonsson et al. 2001). Although there are subtle differences among these parameters, and data may need to be handled differently when parametric statistical comparisons are sought (e.g., arcsine square root transformation in the case of percent litter mass remaining), all three should give useful results. Choice of one or the other parameter will therefore depend to some extent on convenience and arbitrary conventions.

Table 2 shows an example of how metrics based on litter breakdown coefficient may be devised. The simplest case is when leaf breakdown is compared in impacted stream reaches and corresponding reference sites, or at a single site before and after an incident has occurred. The thresholds tentatively proposed in Table 
TABLE 2. Framework of the breakdown rate module for assessing functional stream integrity by means of litter breakdown assays; this module can be complemented by a variety of additional modules.

\begin{tabular}{|c|c|c|c|}
\hline Method & Assessment parameter & Criterion & Score \\
\hline Comparison with reference & $\begin{array}{l}\text { Ratio of breakdown coefficient at im- } \\
\text { pacted }\left(k_{\mathrm{i}}\right) \text { and reference }\left(k_{\mathrm{r}}\right) \text { site }\end{array}$ & $\begin{array}{l}k_{\mathrm{i}}: k_{\mathrm{r}}=0.75-1.33 \\
k_{\mathrm{i}}: k_{\mathrm{r}}=0.5-0.75 \text { or } 1.33-2.0 \\
k_{\mathrm{i}}: k_{\mathrm{r}}<0.5 \text { or }>2.0\end{array}$ & $\begin{array}{l}2 \\
1 \\
0\end{array}$ \\
\hline Absolute value & $\begin{array}{l}\text { Breakdown coefficien at impacted site } \\
\quad\left(k_{\mathrm{i}}\right)\end{array}$ & $\begin{array}{l}k_{\mathrm{i}}=0.01-0.03 / \mathrm{d} \\
k_{\mathrm{i}}=0.005-0.01 / \mathrm{d} \text { or } 0.03-0.05 / \mathrm{d} \\
k_{\mathrm{i}}<0.005 / \mathrm{d} \text { or }>0.05 / \mathrm{d}\end{array}$ & $\begin{array}{l}2 \\
1 \\
0\end{array}$ \\
\hline Absolute value of ratio & $\begin{array}{l}\text { Ratio of breakdown coefficient in } \\
\text { coarse }\left(k_{\mathrm{c}}\right) \text { and fin }\left(k_{\mathrm{f}}\right) \text { mesh bags } \uparrow\end{array}$ & $\begin{array}{l}k_{\mathrm{c}}: k_{\mathrm{f}}=1.2-1.5 \\
k_{\mathrm{c}}: k_{\mathrm{f}}=1.5-2.0 \text { or }<1.2 \\
k_{\mathrm{c}}: k_{\mathrm{f}}>2.0\end{array}$ & $\begin{array}{l}2 \\
1 \\
0\end{array}$ \\
\hline
\end{tabular}

$\dagger$ If sizable numbers of shredders are predicted to occur in the stream.

2 are derived from information, although rather limited at present, on natural variability in both space and time. Variability at the reach scale has been examined in a few studies. For example, Fabre and Chauvet (1998) found breakdown coefficien ( $k$ values) of alder leaves to vary from $0.0204 / \mathrm{d}$ to $0.0365 / \mathrm{d}$ at seven sites in a mountain stream (their sites S4-S10). The lower and upper limits of this range correspond to $75 \%$ and $133 \%$ of the average breakdown coefficien calculated for all sites taken together. A similar range is obtained for the interannual fluctuation in breakdown rates of both maple $(n=7)$ and rhododendron $(n=6)$ leaves decomposing in an Appalachian Mountain stream, Satellite Branch (Webster et al. 1999). Thus we conclude that at the present state of knowledge, breakdown coeffi cients within the limits of $75-133 \%$ around the mean of a local reference system reveal no clear evidence of an impact on ecosystem functioning. This situation is given the score 2 in Table 2.

The data set collected by Jonsson et al. (2001) can be used to assess the magnitude of natural variability at a scale larger than the reach. The study comprised a total of 23 boreal streams of different size (firs to seventh order), located up to $700 \mathrm{~km}$ apart within an ecoregion and sampled in two consecutive years. The exponential breakdown coefficient of alder leaves deduced from this study $(k=0.0079-0.0357 / \mathrm{d})$ correspond to relative range limits of $\sim 50-200 \%$ of the mean. Deviations of that magnitude, or more, are indeed regularly encountered in impacted streams (Table $1)$. Young et al. (1994) found ratios of breakdown coefficient between impacted and reference streams $\left(k_{\mathrm{i}}\right.$ : $k_{\mathrm{r}}$ ) of $\sim 3.0$ in a comparison of three streams surrounded by agricultural land with three less modifie streams running through natural grassland. Similarly, rates of leaf breakdown in the six most heavily polluted streams studied by Niyogi et al. (2001) were reduced to 18 $32 \%$ of the average of their nine reference systems. We thus propose as a starting point that breakdown rates outside the apparent range of natural variability at the catchment or regional scale $(50-200 \%$ of the mean) may be considered indicative of severely compromised stream functioning (score 0 in Table 2).
In many situations, a reference situation is not readily available. In these cases, it would be advantageous to be able to resort to absolute target values. As an example we provide target values for alder leaves $(\mathrm{Al}$ nus glutinosa (L.) Gaertn.) calculated from litter breakdown experiments conducted in softwater upland streams in Europe (e.g., Gessner and Chauvet 1994, Canhoto and Graç a 1996, Fabre and Chauvet 1998, Pozo et al. 1998, Hieber and Gessner 2002); target values for other leaf species and regions will differ from those in Table 2, often being lower (Petersen and Cummins 1974, Webster and Benfiel 1986, Webster et al. 1995, 1999). Standardization of litter quality and appropriate classificatio of streams become especially critical when absolute values are used. To start with, stream categories could be define following existing schemes based on morphological, chemical, and/or structural biological criteria (e.g., Rosgen 1996).

Improved sensitivity and robustness of litter breakdown assays may be achieved when ratios of breakdown rates rather than plain values are used. For examples, the ratio of breakdown coefficient in fine mesh and coarse-mesh bags could prove powerful, because changes in the ratio would indicate a shifting balance in the contribution of microorganisms and detritivorous invertebrates (shredders), thus accounting for some of the potential compensatory responses. Similarly, ratios of breakdown coefficient of fast-decomposing and recalcitrant leaf species might be useful, if different mechanisms contribute to the breakdown of the two types of leaves and/or consideration of time scales is important in the assessment of the examined anthropogenic stress. Lastly, as suggested by Stevens and Cummins (1999), "predictability" of breakdown rates, rather than rates per se, might be used to indicate impairment of functional integrity.

In addition to metrics relating directly to litter mass loss, a number of other parameters associated with litter breakdown are theoretically available for assessment purposes. Some of those constitute structural measures associated with litter breakdown, and thus do not assess an ecosystem-level process per se. Examples are the abundance or biomass of shredders, various metrics 
relating to litter-associated invertebrate communities (Wallace et al. 1996, Pascoal et al. 2001), or the relative importance of bacteria and fungi. On the other hand, parameters such as nitrogen and phosphorus immobilization in decomposing leaves offer possible targets for the examination of additional processes linked to litter breakdown (Leland and Carter 1985).

\section{CONCLUSION}

In conclusion, we propose to implement a complementary approach to assessing ecological integrity of streams consisting in the analysis of ecosystem-level processes in addition to structural biological parameters. A variety of processes hold potential for meeting this objective. Leaf litter breakdown is a good candidate process notably because of its central role in stream ecosystem functioning, relative ease of implementation, and a sizeable background database. Leaf breakdown in streams is governed by a variety of internal and external factors that may complicate separation of effects due to anthropogenic stress and natural variability, thus potentially limiting sensitivity and robustness. However many confounding factors can be controlled by standardizing assessment procedures, including the use of litter from specifie reference leaf species, stream classification and/or comparative approaches. In addition, if breakdown rates per se are not sensitive enough, one may resort to composite parameters such as ratios of breakdown coefficient in coarsemesh and fine-mes bags. Furthermore, analyses may be extended to a wide range of both structural and functional parameters associated with the breakdown process. Ultimately, it is desirable to include additional ecosystem-level processes besides litter breakdown into stream bioassessment, thus strengthening comprehensive assessment of these ecosystems that are persistently exposed to profound anthropogenic stresses.

\section{ACKNOWLEDGMENTS}

This paper is based on a presentation given at the Second International Conference on Plant Litter Processing in Freshwaters held in Lunz, Austria, in October of 1999. M. O. Gessner would like to thank the organizers for inviting him to express the ideas presented here. We also thank C. Bratrich, M. A. Bauchrowitz, C. T. Robinson, and J. V. Ward for constructive comments on the manuscript. Preparation of the manuscript was supported by an exchange grant from the French Embassy in Switzerland. This is a contribution to EAWAG's transdisciplinary project Green Hydropower.

\section{Literature Cited}

Abelho, M., and M. A. S. Graç a. 1996. Effects of eucalyptus afforestation on leaf litter dynamics and macroinvertebrate community structure of streams in Central Portugal. Hydrobiologia 324:195-204.

Allan, J. D., and A. S. Flecker. 1993. Biodiversity conservation in running water. BioScience 43:32-43.

Anderson, N. H., and J. R. Sedell. 1979. Detritus processing by macroinvertebrates in stream ecosystems. Annual Review of Entomology 24:351-377.

Baldy, V., and M. O. Gessner. 1997. Towards a budget of leaf litter decomposition in a first-orde woodland stream.
Comptes-Rendus de l'Académie des Sciences, Série III 320:747-758.

Barbour, M. T., J. Gerritsen, B. D. Snyder, and J. B. Stribling. 1999. Rapid bioassessment protocols for use in streams and wadeable rivers: periphyton, benthic macroinvertebrates and fish Second edition. EPA 841-B-99-002. U.S. Environmental Protection Agency, Offic of Water, Washington, D.C., USA.

Benfield E. F., J. R. Webster, S. W. Golladay, G. T. Peters, and B. M. Stout. 1991. Effects of forest disturbance on leaf breakdown in southern Appalachian streams. Verhandlungen der Internationalen Vereinigung für Theoretische und Angewandte Limnologie 24:1687-1690.

Benfield E. F., J. R. Webster, T. L. Tank, and J. J. Hutchens. 2001. Long-term patterns in leaf breakdown in streams in response to watershed logging. International Review of Hydrobiology 86:467-474.

Benke, A. G. 1990. A perspective on America's vanishing streams. Journal of the North American Benthological Society 43:32-43.

Bermingham, S., L. Maltby, and R. C. Cooke. 1996. Effect of a coal mine effluen on aquatic hyphomycetes. I. Field study. Journal of Applied Ecology 33:1311-1321.

Bird, G. A., and N. K. Kaushik. 1992. Invertebrate colonization and processing of maple leaf litter in a forested and agricultural reach of a stream. Hydrobiologia 234:65-77.

Blöch, H. 1999. The European Union water framework directive: taking European water policy into the next millenium. Water Science and Technology 40:67-71.

Boon, P. 2000. Global perspectives on river conservation. John Wiley and Sons, New York, New York, USA.

Bruns, D. A., G. B. Wiersma, and G. W. Minshall. 1992. Evaluation of community and ecosystem monitoring parameters at a high elevation, Rocky Mountain study site. Environmental Toxicology and Chemistry 11:459-472.

Bunn, S. E., and P. M. Davies. 2000. Biological processes in running waters and their implications for the assessment of ecological integrity. Hydrobiologia 422/423:61-70.

Bunn, S. E., P. M. Davies, and T. D. Mosisch. 1999. Ecosystem measures of river health and their response to riparian and catchment degradation. Freshwater Biology 41: 333-345.

Canhoto, C., and M. A. S. Graç a. 1996. Decomposition of Eucalyptus globulus leaves and three native leaf species (Alnus glutinosa, Castanea sativa and Quercus faginea) in a Portuguese low-order stream. Hydrobiologia 333:79-85.

Chapin, F. S., III, B. H. Walker, R. J. Hobbs, D. U. Hooper, J. H. Lawton, O. E. Sala, and D. Tilman. 1997. Biotic control over the functioning of ecosystems. Science 277: 500-504.

Christensen, N. L., A. M. Bartuska, J. H. Brown, S. Carpenter, C. D'Antonio, R. Francis, J. F. Franklin, J. A. MacMahon, R. F. Noss, D. J. Parsons, C. H. Peterson, M. G. Turner, and R. G. Woodmansee. 1996. The report of the Ecological Society of America committee on the scientifi basis for ecosystem management. Ecological Applications 6:665691.

Chung, K., J. B. Wallace, and J. W. Grubaugh. 1993. The impact of insecticide treatment on abundance, biomass and production of litterbag fauna in a headwater stream: a study of pretreatment, treatment and recovery. Limnologica 28: 93-106.

Convention on Biological Diversity. 1992. United Nations Conference on Environment and Development, Rio de Janeiro, Brazil, 5 June 1992.

Crossey, M. J., and T. W. La Point. 1988. A comparison of periphyton community structural and functional responses to heavy metals. Hydrobiologia 162:109-121.

Cummins, K. W. 1974. Structure and function of stream ecosystems. BioScience 24:631-641. 
Cummins, K. W., M. A. Wilzbach, D. M. Gates, J. B. Perry, and W. B. Taliaferro. 1989. Shredders and riparian vegetation. BioScience 39:24-30.

Dangles, O., and F. Guérold. 1998. A comparative study of beech leaf breakdown, energic content, and associated fauna in acidic and non-acidic streams. Archiv für Hydrobiologie 144:25-39.

Dangles, O., and F. Guérold. 2001. Influenc of shredders in mediating breakdown rates of beech leaves in circumneutral and acidic forest streams. Archiv für Hydrobiologie 151:649-666.

Dynesius, M., and C. Nilsson. 1994. Fragmentation and flo regulation of river systems in the northern third of the world. Science 266:753-762.

Elwood, J. W., J. D. Newbold, A. F. Trimble, and R. W. Stark. 1981. The limiting role of phosphorus in a woodland stream ecosystem: effects of $\mathrm{P}$ enrichment on leaf decomposition and primary producers. Ecology 62:146-158.

Fabre, E., and E. Chauvet. 1998. Leaf breakdown along an altitudinal stream gradient. Archiv für Hydrobiologie 141: 167-179.

Frost, T. M., S. R. Carpenter, A. R. Ives, and T. K. Kratz. 1995. Species compensation and complementarity in ecosystem function. Pages 224-208 in C. G. Jones and J. H. Lawton, editors. Linking species and ecosystems. Chapman and Hall, New York, New York, USA.

Frost, T. M., P. K. Montz, T. K. Kratz, T. Badillo, P. L. Brezonik, M. J. Gonalez, R. G. Rada, C. J. Watras, K. E. Webster, J. G. Wiener, C. E. Williamson, and D. P. Morris. 1999. Multiple stresses from a single agent: diverse responses to the experimental acidificatio of Little Rock Lake, Wisconsin. Limnology and Oceanography 44:784794.

Gergel, S. E., M. G. Turner, and T. T. Kratz. 1999. Dissolved organic carbon as an indicator of the scale of watershed influenc on lakes and rivers. Ecological Applications 9: 1377-1390.

Gessner, M. O., and E. Chauvet. 1994. Importance of stream microfungi in controlling breakdown rates of leaf litter. Ecology 75:1807-1817.

Gessner, M. O., E. Chauvet, and M. Dobson. 1999. A perspective on leaf litter breakdown in streams. Oikos 85:377384.

Gessner, M. O., K. Suberkropp, and E. Chauvet. 1997. Decomposition of plant litter by fungi in marine and freshwater ecosystems. Pages 303-322 in D. T. Wicklow and B. Söderström, editors. The Mycota. Volume IV. Environmental and microbial relationships. Springer-Verlag, Berlin, Germany.

Graç a, M. A. S. 1993. Patterns and processes in detritusbased stream systems. Limnologica 23:107-114.

Grattan, R. M., and K. Suberkropp. 2001. Effects of nutrient enrichment on yellow poplar leaf decomposition and fungal activity in streams. Journal of the North American Benthological Society 20:33-43.

Gray, L. J., and J. V. Ward. 1983. Leaf litter breakdown in streams receiving treated and untreated metal mine drainage. Environment International 9:135-138.

Gregory, S. V., F. J. Swanson, W. A. McKee, and K. W. Cummins. 1991. An ecosystem perspective of riparian zones-focuon links between land and water. BioScience 41:540-551.

Griffith M. B., and S. A. Perry. 1991. Leaf pack processing in two Appalachian mountain streams draining catchments with different management histories. Hydrobiologia 220: 247-254.

Hannah, L., D. Lohse, C. Hutchinson, J. L. Carr, and A. Lankerani. 1994. A preliminary inventory of human disturbance of world ecosystems. Ambio 23:246-250.

Harding, J. S., E. F. Benfield P. V. Bolstad, G. S. Helfman, and E. B. D. Jones, III. 1998. Stream biodiversity: the ghost of land use past. Proceedings of the National Academy of Sciences of the USA 95:14843-14847.

Hieber, M., and M. O. Gessner. 2002. Contribution of stream detritivores, fungi, and bacteria to leaf breakdown based on biomass estimates. Ecology 83:1026-1038.

Hill, B. H., T. J. Gardner, O. F. Ekisola, and G. M. Henebry. 1992. Microbial use of leaf litter in prairie streams. Journal of the North American Benthological Society 11:11-19.

Hill, B. H., A. T. Herlihy, P. R. Kaufmann, and R. L. Sinsabaugh. 1998. Sediment microbial respiration in a synoptic survey of mid-Atlantic region streams. Freshwater Biology 39:493-501.

Hill, B. H., A. T. Herlihy, P. R. Kaufmann, R. J. Stevenson, F. H. McCormick, and C. B. Johnson. 2000. Use of periphyton assemblage data as an index of biotic integrity. Journal of the North American Benthological Society 19: $50-67$.

Hill, B. H., J. M. Lazorchak, F. H. McCormick, and W. T. Willingham. 1997. The effects of elevated metals on benthic community metabolism in a Rocky Mountain stream. Environmental Pollution 95:183-190.

Hunsaker, C. T., R. L. Graham, G. W. Suter, III, R. V. O’Neill, L. W. Barnthouse, and R. H. Gardner. 1990. Assessing ecological risk on a regional scale. Environmental Management 14:325-332.

Jonsson, M., B. Malmqvist, and P.-O. Hoffsten. 2001. Leaf litter breakdown rates in boreal streams: does shredder species richness matter? Freshwater Biology 46:161-171.

Jungwirth, M., S. Muhar, S. Schmutz, B. Vogel, and E. Alvarez. 2000. Assessing the ecological integrity of running waters. Hydrobiologia 422/423.

Karr, J. R. 1991. Biological integrity: a long neglected aspect of water resource management. Ecological Applications 1: 66-84.

Karr, J. R. 1999. Definin and measuring river health. Freshwater Biology 41:221-234.

Kimmel, W. G., D. J. Murphey, W. E. Sharpe, and D. R. DeWalle. 1985. Macroinvertebrate community structure and detritus processing rates in two southwestern Pennsylvania streams acidifie by atmospheric deposition. Hydrobiologia 124:97-102.

Leland, H. V., and J. L. Carter. 1985. Effects of copper on production of periphyton, nitrogen fixatio and processing of leaf litter in a Sierra Nevada, California, stream. Freshwater Biology 15:155-173.

Maloney, D. G., and G. A. Lamberti. 1995. Rapid decomposition of summer-input leaves in a northern Michigan stream. American Midland Naturalist 133:184-195.

Maltby, L. 1992. Detritus processing. Pages 331-353 in P. Calow and G. E. Petts, editors. The rivers handbook. Volume 1. Hydrological and ecological principles. Blackwell Science, Oxford, UK.

Maltby, L., and R. Booth. 1991. The effect of coal-mine effluen on fungal assemblages and leaf breakdown. Water Research 25:247-250.

Maltby, L., D. M. Forrow, A. B. A. Boxall, P. Calow, and C. I. Betton. 1995. The effects of motorway runoff on freshwater ecosystems. 1. Field study. Environmental Toxicology and Chemistry 14:1079-1092.

Martí, E., N. B. Grimm, and S. G. Fisher. 1997. Pre-and postfloo retention efficienc of nitrogen in a Sonoran desert stream. Journal of the North American Benthological Society 16:805-819.

Matthews, R. A., A. L. Buikema, Jr., J. Cairns, Jr., and J. H. Rodgers, Jr. 1982. Biological monitoring. Part IIA. Receiving system functional methods, relationships and indices. Water Research 16:129-139.

Merritt, R. W., M. J. Higgins, K. W. Cummins, and B. Vandeneeden. 1999. The Kissimmee River-riparian marsh eco- 
system, Florida: seasonal differences in invertebrate functional feeding group relationships. Pages 55-79 in D. P. Batzer, R. B. Rader, and S. A. Wissinger, editors. Invertebrates in freshwater wetlands of North America: ecology and management. John Wiley and Sons, New York, New York, USA.

Metcalfe-Smith, J. L. 1994. Biological water-quality assessment of rivers: use of macroinvertebrate communities. Pages $144-170$ in P. Calow and G. E. Petts, editors. The rivers handbook. Volume 2. Hydrological and ecological principles. Blackwell Science, Oxford, UK.

Meyer, J. L. 1997. Stream health: incorporating the human dimension to advance stream ecology. Journal of the North American Benthological Society 16:439-447.

Meyer, J. L., and C. Johnson. 1983. The influenc of elevated nitrate concentration on rate of leaf decomposition in a stream. Freshwater Biology 13:177-183.

Minshall, G. W. 1996. Bringing biology back into water quality assessments. Pages 289-324 in Committee on inland aquatic ecosystems. Freshwater ecosystems: revitalizing educational programs in limnology. Water Science and Technology Board, Commission on Geosciences, Environment, and Resources, National Research Council, USA.

Nelson, S. M. 2000. Leaf pack breakdown and macroinvertebrate colonization: bioassessment tools for a high-altitude regulated system? Environmental Pollution 110:321-329.

Newman, R. M., and J. A. Perry. 1989. The combined effects of chlorine and ammonia on litter breakdown in outdoor experimental streams. Hydrobiologia 184:69-78.

Newman, R. M., J. A. Perry, E. Tam, and R. L. Crawford. 1987. Effects of chronic chlorine exposure on litter processing in outdoor experimental streams. Freshwater Biology 18:415-428.

Niemi, G. J., N. E. Detenbeck, and J. A. Perry. 1993. Comparative analysis of variables to measure recovery rates in streams. Environmental Toxicology and Chemistry 12: 1541-1547.

Niyogi, D. K., W. M. Lewis, Jr., and D. M. McKnight. 2001. Litter breakdown in mountain streams affected by acid mine drainage: biotic mediation of abiotic controls. Ecological Applications 11:506-516.

Norris, R. H., and C. P. Hawkins. 2000. Monitoring river health. Hydrobiologia 435:5-17.

Norris, R. H., and M. C. Thoms. 1999. River health. Freshwater Biology 41(2).

Pascoal, C., F. Cássio, and P. Gomes. 2001. Leaf processing rates: a measure of water quality? International Review of Hydrobiology 86:407-416.

Paul, R. W., Jr., E. F. Benfield and J. Cairns, Jr. 1978. Effects of thermal discharge on leaf decomposition in a river ecosystem. Verhandlungen der Internationalen Vereinigung für Theoretische und Angewandte Limnologie 20:1759-1766.

Petersen, R. C., and K. W. Cummins. 1974. Leaf processing in a woodland stream. Freshwater Biology 4:343-368.

Petts, J. 1999. Handbook of environmental impact assessment. Two volumes. Blackwell Science, Oxford, UK.

Pidgeon, R. W. J., and S. C. Cairns. 1981. Decomposition and colonisation by invertebrates of native and exotic leaf material in a small stream in New England (Australia). Hydrobiologia 77:113-127.

Pozo, J., A. Basaguren, A. Elósegui, J. Molinero, E. Fabre, and E. Chauvet. 1998. Afforestation with Eucalyptus globulus and leaf litter decomposition in streams of northern Spain. Hydrobiologia 373/374:101-109.

Rapport, D. J., R. Costanza, and A. J. McMichael. 1998. Assessing ecosystem health. Trends in Ecology and Evolution 13:397-402.

Rawer-Jost, C., J. Böhmer, J. Blank, and H. Rahmann. 2000. Macroinvertebrate functional feeding group methods in ecological assessment. Hydrobiologia 422/423:225-232.
Reice, S. R., and M. Wohlenberg. 1993. Monitoring freshwater benthic macroinvertebrates and benthic processes: measures for assessment of ecosystem health. Pages 287 305 in D. M. Rosenberg and V. H. Resh, editors. Freshwater biomonitoring and benthic macroinvertebrates. Chapman and Hall, New York, New York, USA.

Robinson, C. T., and M. O. Gessner. 2000. Nutrient addition accelerates leaf breakdown in an alpine springbrook. Oecologia 122:258-263.

Rodgers, J. H., Jr., K. L. Dickson, and J. Cairns, Jr. 1979. A review and analysis of some methods used to measure functional aspects of periphyton. Pages 142-167 in R. L. Weitzel, editor. Methods and measurements of periphyton communities: a review. ASMT STP 690. American Society for Testing and Materials.

Rosenberg, D. M., P. McCully, and C. M. Pringle. 2000. Global-scale environmental effects of hydrological alterations: introduction. BioScience 50:746-751.

Rosenberg, D. M., and V. H. Resh, editors. 1993. Freshwater biomonitoring and benthic macroinvertebrates. Chapman and Hall, New York, New York, USA.

Rosgen, D. L. 1996. Applied river morphology. Wildland hydrology, Pagosa Springs, Colorado, USA.

Rudd, J. W. M., C. A. Kelly, D. W. Schindler, and M. A. Turner. 1988. Disruption of the nitrogen cycle in acidifie lakes. Science 240:1515-1517.

Sabater, S., A. Butturini, I. Muñoz, A. Romaní, J. Wray, and F. Sabater. 1998. Effects of removal of riparian vegetation on algae and heterotrophs in a Mediterranean stream. Journal of Aquatic Ecosystem Stress and Recovery 6:129-140.

Scheiring, J. F. 1993. Effects of surface-mine drainage on leaf litter insect communities and detritus processing in headwater streams. Journal of the Kansas Entomological Society 66:31-40.

Schindler, D. W. 1987. Detecting ecosystem responses to anthropogenic stress. Canadian Journal of Fisheries and Aquatic Sciences 44(Supplement):6-25.

Schultheis, A. S., M. Sanchez, and A. C. Hendricks. 1997. Structural and functional responses of stream insects to copper pollution. Hydrobiologia 346:85-93.

Schulze, D. J., and K. F. Walker. 1997. Riparian eucalypts and willows and their significanc for aquatic invertebrates in the River Murray, South Australia. Regulated Rivers 13: 557-577.

Short, R. A., and J. V. Ward. 1980. Leaf litter processing in a regulated Rocky Mountain stream. Canadian Journal of Fisheries and Aquatic Sciences 37:123-127.

Sinsabaugh, R. L., S. W. Golladay, and A. E. Linkins. 1991. Comparison of epilithic and epixylic biofil development in a boreal river. Freshwater Biology 25:179-187.

Smith, V. H. 1998. Cultural eutrophication of inland, estuarine, and coastal waters. Pages 7-49 in M. L. Pace and P. M. Groffman, editors. Successes, limitations, and frontiers in ecosystem science. Springer-Verlag, New York, New York, USA.

Smock, L. A., and C. M. MacGregor. 1988. Impact of the American chestnut blight on aquatic shredding macroinvertebrates. Journal of the North American Benthological Society 7:212-221.

Stanford, J. A., and G. C. Poole. 1996. A protocol for ecosystem management. Ecological Applications 6:741-744.

Statzner, B., B. Bis, S. Dolédec, and P. Usseglio-Polatera. 2001. Perspectives for biomonitoring at large scales: a unifie measure for the functional composition of invertebrate communities in European running waters. Basic and Applied Ecology 2:73-85.

Stevens, M. H. H., and K. W. Cummins. 1999. Effects of long-term disturbance on riparian vegetation and in-stream characteristics. Journal of Freshwater Ecology 14:1-17.

Stout, B. M., III, and C. B. Coburn, Jr. 1989. Impact of 
highway constructions on leaf processing in aquatic habitats of eastern Tennessee. Hydrobiologia 178:233-242.

Stout, R. J., and W. E. Cooper. 1983. Effect of $p$-Cresol on leaf decomposition and invertebrate colonization in experimental outdoor streams. Canadian Journal of Fisheries and Aquatic Sciences 40:1647-1657.

Suberkropp, K. F. 1998. Microorganisms and organic matter decomposition. Pages 120-143 in R. J. Naiman and R. E. Bilby, editors. River ecology and management: lessons from the Pacifi Coastal Ecoregion. Springer-Verlag, New York, New York, USA.

Suberkropp, K., and E. Chauvet. 1995. Regulation of leaf breakdown by fungi in streams: influence of water chemistry. Ecology 76:1433-1445.

Suberkropp, K., and J. B. Wallace. 1992. Aquatic hyphomycetes in insecticide-treated and untreated streams. Journal of the North American Benthological Society 11:165171.

Triska, F. J., and J. R. Sedell. 1976. Decomposition of four species of leaf litter in response to nitrate manipulation. Ecology 57:783-792.

Tuchman, N. C., and R. H. King. 1993. Changes in mechanisms of summer detritus processing between wooded and agriculture sites in a Michigan headwater stream. Hydrobiologia 268: 115-127.

Vitousek, P. M., H. A. Mooney, J. Lubchenco, and J. M. Melillo. 1997. Human domination of Earth's ecosystems. Science 277:494-499.

Vought, L. B.-M., A. Kullberg, and R. C. Petersen. 1998. Effect of riparian structure, temperature, and channel morphometry on detritus processing in channelized and natural woodland streams in southern Sweden. Aquatic Conservation of Marine and Freshwater Ecosystems 8:273-285.

Wallace, J. B., S. L. Eggert, J. L. Meyer, and J. R. Webster. 1997. Multiple trophic levels of a forest stream linked to terrestrial litter inputs. Science 277:102-104.

Wallace, J. B., J. W. Grubaugh, and M. R. Whiles. 1996. Biotic indices and stream ecosystem processes: results from an experimental study. Ecological Applications 61:140151.

Wallace, J. B., and J. R. Webster. 1996. The role of macroin- vertebrates in stream ecosystem function. Annual Review of Entomology 41:115-139.

Ward, J. V. 1998. Riverine landscapes: biodiversity patterns, disturbance regimes, and aquatic conservation. Biological Conservation 83:269-278.

Webster, J. R., and E. F. Benfield 1986. Vascular plant breakdown in freshwater ecosystems. Annual Review of Ecology and Systematics 17:567-594.

Webster, J. R., E. F. Benfield T. P. Ehrman, M. A. Schaeffer, J. L. Tank, J. J. Hutchens, and D. J. D’Angelo. 1999. What happens to allochthonous material that falls into streams? A synthesis of new and published information from Coweeta. Freshwater Biology 41:687-705.

Webster, J. R., and J. Meyer. 1997. Stream organic matter budgets. Journal of the North American Benthological Society 16:3-161.

Webster, J. R., and J. B. Waide. 1982. Effects of forest clearcutting on leaf breakdown in a southern Appalachian stream. Freshwater Biology 12:331-344.

Webster, J. R., J. B. Wallace, and E. F. Benfield 1995. Organic processes in streams of the Eastern United States. Pages 117-187 in C. E. Cushing, K. W. Cummins, and G. W. Minshall, editors. Ecosystems of the world 22, River and stream ecosystems. Elsevier, New York, New York, USA.

Whiles, M. R., and J. B. Wallace. 1997. Leaf litter decomposition and macroinvertebrate communities in headwater streams draining pine and hardwood catchments. Hydrobiologia 353:107-119.

Whiles, M. R., J. B. Wallace, and K. Chung. 1993. The influenc of Lepidostoma (Trichoptera: Lepidostomatidae) on recovery of leaf-litter processing in disturbed headwater streams. American Midland Naturalist 130:356-363.

Young, R. G., and A. D. Huryn. 1999. Effects of land use on stream metabolism and organic matter turnover. Ecological Applications 9:1359-1376.

Young, R. G., A. D. Huryn, and C. R. Townsend. 1994. Effects of agricultural development on processing of tussock leaf litter in high country New Zealand streams. Freshwater Biology 32:413-427.

Zwick, P. 1992. Stream habitat fragmentation-ahreat to biodiversity. Biodiversity and Conservation 1:80-97. 